\title{
Carbon nanotubes as catalysts for wet peroxide oxidation: The effect of surface chemistry
}

\author{
Maria Martin-Martinez ${ }^{\mathrm{a}, \mathrm{e}}$, Bruno F. Machado ${ }^{\mathrm{b}}$, Philippe Serp ${ }^{\mathrm{c}}$, Sergio Morales-Torres ${ }^{\mathrm{d}}$, \\ Adrián M.T. Silva ${ }^{\mathrm{b}}$, José L. Figueiredo ${ }^{\mathrm{b}}$, Joaquim L. Faria ${ }^{\mathrm{b}}$, Helder T. Gomes ${ }^{\mathrm{a}, \mathrm{b}}$,* \\ ${ }^{a}$ Centro de Investigação de Montanha (CIMO), Instituto Politécnico de Bragança, Campus de Santa Apolónia, 5300-253 Bragança, Portugal \\ ${ }^{\mathrm{b}}$ Laboratory of Separation and Reaction Engineering - Laboratory of Catalysis and Materials (LSRE-LCM), Departamento de Engenharia Química, Faculdade de \\ Engenharia, Universidade do Porto, Rua Dr. Roberto Frias s/n, 4200-465 Porto, Portugal \\ ${ }^{\mathrm{c}}$ Laboratoire de Chimie de Coordination UPR CNRS 8241, Composante ENSIACET, Université de Toulouse, UPS-INP-LCC 4 allé Emile Monso BP 44362 , 31030 Toulouse \\ Cedex 4, France \\ ${ }^{\mathrm{d}}$ Carbon Materials Research Group, Department of Inorganic Chemistry, Faculty of Sciences, University of Granada, Campus Fuentenueva s/n, 18071 Granada, Spain

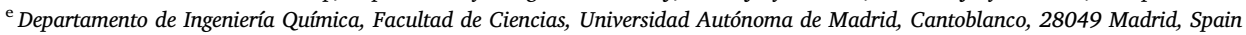

\section{A R T I C L E I N F O}

\section{Keywords:}

Carbon nanotubes

Surface modification

CWPO

4-Nitrophenol

\begin{abstract}
A B S T R A C T
Three magnetic carbon nanotube (CNT) samples, named A30 (N-doped), E30 (undoped) and E10A20 (selectively N-doped), synthesized by catalytic chemical vapor deposition, were modified by introducing oxygenated surface groups (oxidation with $\mathrm{HNO}_{3}$, samples CNT-N), and by heat treatment at $800{ }^{\circ} \mathrm{C}$ for the removal of surface functionalities (samples CNT-HT). Both treatments lead to higher specific surface areas. The acid treatment results in more acidic surfaces, with higher amounts of oxygenated species being introduced on $\mathrm{N}$ doped surfaces. Heat-treated samples are less hydrophilic than those treated with nitric acid, heat treatment leading to neutral or basic surfaces, only N-quaternary and N-pyridinic species being found by XPS on N-doped surfaces. These materials were tested in the catalytic wet peroxide oxidation (CWPO) of highly concentrated 4-nitrophenol solutions (4-NP, $5 \mathrm{~g} \mathrm{~L}^{-1}$ ) at atmospheric pressure, $\mathrm{T}=50{ }^{\circ} \mathrm{C}$ and $\mathrm{pH}=3$, using a catalyst load of $2.5 \mathrm{~g} \mathrm{~L}^{-1}$ and the stoichiometric amount of $\mathrm{H}_{2} \mathrm{O}_{2}$ needed for the complete mineralization of 4-NP. The high temperature treatment enhanced significantly the activity of the CNTs towards CWPO, evaluated in terms of 4-NP and total organic carbon conversion, due to the increased hydrophobicity of their surface. In particular, E30HT and E10A20HT were able to remove $c a$. 100\% of 4-NP after $8 \mathrm{~h}$ of operation. On the other hand, by treating the CNTs with $\mathrm{HNO}_{3}$, the activity of the less hydrophilic samples decreased upon increasing the concentration of surface oxygen-containing functionalities, whilst the reactivity generated inside the opened nanotubes improved the activity of the highly hydrophilic A30 N.
\end{abstract}

\section{Introduction}

Carbon materials, such as activated carbon, carbon gels, graphite, graphene, and carbon nanofibers and nanotubes (CNTs), have been extensively used in different heterogeneous catalytic processes [1-5]. Among them, CNTs are particularly suitable for liquid-phase reactions (as catalysts or catalyst supports) in different environmental processes, owing to their particular mechanical, electronic, and thermal properties $[6,7]$. CNTs can be synthesized by different procedures, such as arc discharge [8], laser ablation [9], and plasma torch [10], but catalytic chemical vapor deposition (CVD) has been the most widely used method for their production, including at the industrial scale [11].
During catalytic CVD, a carbon-containing precursor (methane, acetylene, ethylene, benzene, etc.) first decomposes on a metallic surface ( $\mathrm{Fe}, \mathrm{Co}, \mathrm{Ni})$, generally in the presence of hydrogen. Then, the carbon atoms diffuse on or in the metallic phase and precipitate to produce a CNT $[1,12]$. Due to the generally high synthesis temperatures, and reductive synthesis atmosphere, the surface of these materials commonly presents low amounts of heteroatoms (e.g., O), rendering them mostly inert $[13,14]$. One way to increase their reactivity is to introduce surface groups through thermal, chemical, or physical treatments. This allows the nature and concentration of surface functional groups to be fine-tuned to specific applications [15]. For example, oxidation treatments with nitric acid, hydrogen peroxide, or ozone introduce oxygen-

\footnotetext{
*Corresponding author at: Centro de Investigação de Montanha (CIMO), Instituto Politécnico de Bragança, Campus de Santa Apolónia, 5300-253 Bragança, Portugal.

E-mail address: htgomes@ipb.pt (H.T. Gomes).
} 
containing surface groups such as carboxylic acids and anhydrides, lactones, phenols, carbonyls, and quinones, with different acidic/basic properties [16,17]. Ammonia, urea, and melamine [18,19] are commonly used for the incorporation of nitrogen-containing surface groups (e.g., ex situ at high temperatures), which are known to contribute to the basicity of CNTs [20,21]. Nevertheless, nitrogen atoms can also be introduced during the in situ CVD growth of CNTs, resulting in materials with new properties such as increased polarity and electrical conductivity, improved CNTs dispersion in liquid media, higher reactivity towards different molecules, and lower toxicity [22-26]. Moreover, it is known that, due to their electron donating capacity, the presence of $\mathrm{N}$ groups on the CNT surface enhances their activity towards hydrogen peroxide $\left(\mathrm{H}_{2} \mathrm{O}_{2}\right)$ decomposition into $\mathrm{HO}^{\circ}$ radicals, the preliminary step for several catalytic processes $[27,28]$. The acidity of CNTs can also be increased by oxidation with sulfuric acid, due to the introduction of sulfonic acid and thiol groups [29-31]. In order to control the CNT surface chemistry, certain functional groups can be removed following a thermal treatment. Working at specific temperatures under inert atmosphere, it is possible to remove selectively different types of surface groups $[17,32,33]$.

Catalytic wet peroxide oxidation (CWPO) uses $\mathrm{H}_{2} \mathrm{O}_{2}$ as a source of hydroxyl radicals ( $\mathrm{HO}^{\circ}$ ) for the oxidation of organic species. This process has been successfully used for the treatment of aqueous effluents containing recalcitrant and non-biodegradable compounds from pharmaceutical and petrochemical industries, among others, under relatively mild operation conditions $[34,35]$. These types of compounds are difficult to remove by conventional biological processes, especially when present at high concentrations $\left(1-10 \mathrm{~g} \mathrm{~L}^{-1}\right)$. Among organic pollutants, phenol and its derivatives have received increasing attention in the last years due to their high toxicity. Some of the most toxic members of the phenol family are chloro- and nitro-phenols, commonly used as pesticides and antibacterials. The classical heterogeneous catalysts used in CWPO consist of an active phase, mainly Fe, supported on a porous material such as activated carbon, alumina, or zeolites. However, they usually suffer from severe deactivation due to leaching of the metallic phase into the reaction medium, with further steps being needed in the overall treatment process to remove or recover the metals from the treated wastewaters [36-39]. In addition, rather than attacking the pollutant molecules, hydroxyl radicals can also recombine, originating non-reactive species like $\mathrm{H}_{2} \mathrm{O}$ and $\mathrm{O}_{2}$ [25]. In order to overcome this limitation, the properties of the catalysts for CWPO can be improved through surface chemical modification. Basic functionalities enhance $\mathrm{H}_{2} \mathrm{O}_{2}$ decomposition. Basic oxygen-containing functionalities (e.g., chromene, pyrone and quinones) are electron donating species, promoting the decomposition of $\mathrm{H}_{2} \mathrm{O}_{2}$ to $\mathrm{HO}^{-}$[35,40-42]. Moreover, basic nitrogen-containing functionalities have been related with increased rates of $\mathrm{H}_{2} \mathrm{O}_{2}$ decomposition [27]. On the other hand, acidic oxygen-containing functionalities withdraw electrons from the catalyst surface, hindering their use in $\mathrm{H}_{2} \mathrm{O}_{2}$ attack. Therefore, the presence of acidic functionalities may limit the CWPO process [43,44].

Instead of supporting metallic particles on CNTs, in this work, a Fe/ $\gamma-\mathrm{Al}_{2} \mathrm{O}_{3}$ catalyst has been used for the synthesis of $\mathrm{N}$-doped and undoped CNTs by CVD, enabling the incorporation of Fe magnetic particles within the CNT structure. After inducing different surface properties to the synthesized CNTs by oxidation with nitric acid and thermal treatment at $800{ }^{\circ} \mathrm{C}$, the materials have been tested as catalysts for the CWPO of 4-nitrophenol (4-NP) solutions. High pollutant concentrations $\left(5 \mathrm{~g} \mathrm{~L}^{-1}\right)$ were used to simulate highly loaded wastewaters.

\section{Materials and methods}

\subsection{Chemicals}

4-NP (98 wt.\%) was purchased from Acros Organics. $\mathrm{H}_{2} \mathrm{O}_{2}(30 \%, \mathrm{w} / \mathrm{v}$ ), 1,4-benzoquinone $\left(\mathrm{C}_{6} \mathrm{H}_{4} \mathrm{O}_{2}, 99.5 \mathrm{wt} . \%\right)$, catechol $\left(\mathrm{C}_{6} \mathrm{H}_{6} \mathrm{O}_{2}, 98 \mathrm{wt} . \%\right)$ and 4-nitrocatechol $\left(\mathrm{C}_{6} \mathrm{H}_{5} \mathrm{NO}_{4}, 98 \mathrm{wt} . \%\right)$ were obtained from Fluka. Formic acid $\left(\mathrm{CH}_{2} \mathrm{O}_{2}, 98\right.$ wt.\%), o-phenanthroline $\left(\mathrm{C}_{12} \mathrm{H}_{8} \mathrm{~N}_{2}, 99\right.$ wt.\%) and sodium hydroxide ( $\mathrm{NaOH}, 98 \mathrm{wt} . \%)$ were acquired from Panreac. Acetic acid $\left(\mathrm{CH}_{3} \mathrm{COOH}\right.$, glacial acetic acid), acetonitrile $\left(\mathrm{CH}_{3} \mathrm{CN}\right.$, HPLC grade, 99.99 wt.\%), methanol $\left(\mathrm{CH}_{3} \mathrm{OH}\right.$, HPLC grade, 99.99 wt.\%) and L-ascorbic acid $\left(\mathrm{C}_{6} \mathrm{H}_{8} \mathrm{O}_{6}, 99\right.$ wt.\%) were purchased from Fisher Chemical. Hydroquinone $\left(\mathrm{C}_{6} \mathrm{H}_{6} \mathrm{O}_{2}, 99\right.$ wt.\%), maleic acid $\left(\mathrm{C}_{4} \mathrm{H}_{4} \mathrm{O}_{4}, 99\right.$ wt.\%), malic acid $\left(\mathrm{C}_{4} \mathrm{H}_{6} \mathrm{O}_{5}, 99\right.$ wt.\%), malonic acid $\left(\mathrm{C}_{3} \mathrm{H}_{4} \mathrm{O}_{4}, 99\right.$ wt.\%), oxalic acid $\left(\mathrm{C}_{2} \mathrm{H}_{2} \mathrm{O}_{4}, 99\right.$ wt.\%), phenol $\left(\mathrm{C}_{6} \mathrm{H}_{5} \mathrm{OH}, 99 \mathrm{wt} . \%\right)$, iron(II) chloride tetrahydrate $\left(\mathrm{FeCl}_{2} \cdot 4 \mathrm{H}_{2} \mathrm{O}, 99 \mathrm{wt} . \%\right)$, hydrochloric acid ( $\left.\mathrm{HCl}, 37 \mathrm{wt} . \%\right)$, potassium nitrate $\left(\mathrm{KNO}_{3}, 99 \mathrm{wt} \%\right.$ ), titanium(IV) oxysulphate $\left(\mathrm{TiO}_{2} 15 \mathrm{wt} . \%\right.$ in dilute sulphuric acid, 99.99\%) and sodium sulphite $\left(\mathrm{Na}_{2} \mathrm{SO}_{3}, 98 \mathrm{wt} . \%\right)$ were obtained from Sigma-Aldrich. Sulphuric acid $\left(\mathrm{H}_{2} \mathrm{SO}_{4}, 96-98\right.$ wt.\%) and nitric acid $\left(\mathrm{HNO}_{3}, 65 \mathrm{wt} . \%\right)$ were acquired from Riedel-de-Haën and ammonium acetate $\left(\mathrm{CH}_{3} \mathrm{COONH}_{4}, 98 \mathrm{wt}\right.$.\%) was obtained from Pronalab. All chemicals were used as received without further purification. Distilled water was used throughout the work, except for mobile phase preparation, where ultrapure water was employed.

\subsection{Synthesis and modification of carbon nanotubes}

The original CNTs were synthesized by a CVD process in a fluidized bed reactor, as described elsewhere [24]. The CNTs were grown with a $\mathrm{Fe} / \gamma-\mathrm{Al}_{2} \mathrm{O}_{3}(20 \mathrm{wt} . \% \mathrm{Fe})$ catalyst using ethylene as carbon source and acetonitrile as carbon/nitrogen source. The $\mathrm{Fe} / \gamma-\mathrm{Al}_{2} \mathrm{O}_{3}$ catalyst was prepared by impregnation, using a $\mathrm{FeCl}_{2} \cdot 4 \mathrm{H}_{2} \mathrm{O}$ solution, and activated by reduction with $\mathrm{H}_{2}$ at $650^{\circ} \mathrm{C}$ for $30 \mathrm{~min}$, as described by Purceno et al. [24]. Three different samples were produced by feeding to the fluidized bed reactor: (i) ethylene alone for $30 \mathrm{~min}$ (sample E30); (ii) ethylene for $10 \mathrm{~min}$, followed by acetonitrile for $20 \mathrm{~min}$ (E10A20); and (iii) acetonitrile alone for $30 \mathrm{~min}$ (A30). The synthesized CNTs were purified under reflux at $140{ }^{\circ} \mathrm{C}$, with an aqueous solution of $\mathrm{H}_{2} \mathrm{SO}_{4}$ ( 50 vol.\%) for $3 \mathrm{~h}$ to facilitate the total dissolution of both the alumina and exposed Fe particles. Each sample then underwent two different treatments (thermal and chemical), resulting in the production of six additional materials. The thermal treatment was carried out to remove surface functionalities; it consisted on heating the CNT samples under $\mathrm{N}_{2}$ atmosphere $\left(100 \mathrm{~cm}^{3} \mathrm{~min}^{-1}\right)$ at $120^{\circ} \mathrm{C}$ for $60 \mathrm{~min}$, followed by heating at $400^{\circ} \mathrm{C}(60 \mathrm{~min}), 600^{\circ} \mathrm{C}(60 \mathrm{~min})$ and $800^{\circ} \mathrm{C}(240 \mathrm{~min})$, in a vertical furnace $\left(2^{\circ} \mathrm{C} \mathrm{min}^{-1}\right.$ heating ramp between each temperature). On the other hand, the chemical treatment consisted in the oxidation of the original CNT samples with nitric acid to incorporate surface Ocontaining functionalities, adapting the experimental procedure described elsewhere [19]. A $20 \mathrm{~g} \mathrm{~L}^{-1}$ mixture containing CNTs and nitric acid $\left(7 \mathrm{~mol} \mathrm{~L}^{-1}\right)$ was maintained at boiling temperature for $3 \mathrm{~h}$ in a $250 \mathrm{~mL}$ round-bottom flask. The obtained oxidized solids were thoroughly washed with distilled water until stabilization of the $\mathrm{pH}$ of the rinsing waters, and dried in an oven at $110^{\circ} \mathrm{C}$ for $24 \mathrm{~h}$. The samples were named as the original CNT, (E30, E10A20, and A30), followed by "HT" for the heat-treated samples or "N" for the nitric acid-treated ones.

\subsection{Characterization}

The porous structure of the materials was characterized using $\mathrm{N}_{2}$ adsorption-desorption at $-196{ }^{\circ} \mathrm{C}$ (Tristar II 3020, Micromeritics). The samples were previously outgassed for $12 \mathrm{~h}$ at $150{ }^{\circ} \mathrm{C}$ at a residual pressure of $10^{-3}$ Torr (VacPrep 061, Micromeritics). The apparent surface areas $\left(\mathrm{S}_{\mathrm{BET}}\right)$ were calculated by the BET equation [45] and total pore volumes $\left(\mathrm{V}_{\text {pore }}\right)$ were estimated using the BJH method [46].

Transmission Electron Microscopy (TEM) images were obtained using a JEOL 1011 microscope operating at $100 \mathrm{kV}$. Average CNT diameters were calculated from statistical distributions from TEM images.

Elemental analyses were performed on a Vario MICRO Cube system (C, H, N and S), and on a rapid OXY cube analyser (O), from Elementar; $\mathrm{C}, \mathrm{H}, \mathrm{N}$ and $\mathrm{S}$ contents were determined by combustion of the sample at $1050{ }^{\circ} \mathrm{C}$, whereas $\mathrm{O}$ content was determined by pyrolysis at $1450^{\circ} \mathrm{C}$. 
The results correspond to the average of three independent measurements, using a daily calibration with a standard compound.

The chemical surface composition of the CNTs was analyzed by Xray Photoelectron Spectroscopy (XPS, Kratos AXIS Ultra HSA spectrometer), using $\mathrm{Mg}-\mathrm{K} \alpha$ radiation $(1486.7 \mathrm{eV})$. The elements present and their corresponding concentrations were determined by recording general XPS spectra, scanning up to a binding energy (BE) of $1300 \mathrm{eV}$. The C1s peak $(284.6 \mathrm{eV})$ was taken as an internal standard to correct the shift in BE caused by sample charging. The BE of the C1s, N1s, O1s and $\mathrm{Fe} 2 \mathrm{p}_{3 / 2}$ core levels and the full-width-at-half-maximum values were used to assess the chemical state of these elements at the catalyst surface, according to the NIST database.

Temperature programmed desorption (TPD) analyses were performed by heating $0.1 \mathrm{~g}$ of the carbon sample, placed in a quartz tube, defining a heating ramp of $5{ }^{\circ} \mathrm{C} \mathrm{min}{ }^{-1}$ from room temperature up to $1000^{\circ} \mathrm{C}$ under $\mathrm{N}_{2}$ atmosphere $\left(1000 \mathrm{~cm}^{3} \mathrm{~min}^{-1}\right)$. The oxygenated surface groups present in each sample decompose as $\mathrm{CO}$ and/or $\mathrm{CO}_{2}$ [47], and their resulting concentrations were monitored during the thermal analysis using a SIEMENS Ultramat 22 gas analyzer. Peak deconvolution of the TPD profiles (multiple Gaussian functions) was carried out using Origin Pro 9.0 software, according to the literature [47].

The $\mathrm{pH}$ of the point of zero charge $\left(\mathrm{pH}_{\mathrm{PZC}}\right)$ was determined by $\mathrm{pH}$ drift tests adapting the procedure described elsewhere [48]. Briefly, five $\mathrm{NaCl}(0.01 \mathrm{M})$ solutions were prepared as electrolyte with varying initial $\mathrm{pH}$ (range 2-11, using $\mathrm{HCl}$ and $\mathrm{NaOH} 0.1 \mathrm{M}$ solutions). $0.05 \mathrm{~g}$ of carbon sample was added to $20 \mathrm{~mL}$ of each $\mathrm{NaCl}$ solution. The equilibrium $\mathrm{pH}$ of each suspension was measured after $48 \mathrm{~h}$ under stirring $(200 \mathrm{rpm})$ at room temperature. The $\mathrm{pH}_{\mathrm{PZC}}$ value was determined by intercepting the curve 'final $\mathrm{pH} v$ initial $\mathrm{pH}^{\prime}$ ' with the straight line 'initial $\mathrm{pH}=$ final $\mathrm{pH}$ ' [49].

The hydrophobicity/hydrophilicity of the CNTs (in the form of buckypapers) was determined by water contact angle measurements using an Attension optical tensiometer (model Theta) that allowed image acquisition and data analysis. The measurements were performed on dry buckypapers at room temperature using the sessile drop method [50]. For each sample, the contact angle was measured using at least five different locations on the buckypapers in order to determine the average value.

The magnetism of the samples was assessed qualitatively using magnets.

\subsection{4-Nitrophenol removal experiments}

The CWPO runs were carried out in a batch reaction system described elsewhere [25], consisting of a $250 \mathrm{~mL}$, magnetically stirred $(600 \mathrm{rpm})$, glass reactor immersed in an oil bath with temperature control, equipped with a reflux condenser and a sample collection port. In a typical experiment, the reactor was loaded with $50 \mathrm{~mL}$ of a highly concentrated 4-NP aqueous solution $\left(5 \mathrm{~g} \mathrm{~L}^{-1}\right)$ and heated to $50{ }^{\circ} \mathrm{C}$. The $\mathrm{pH}$ was adjusted to 3.0 using $\mathrm{H}_{2} \mathrm{SO}_{4}$ and $\mathrm{NaOH} 0.1 \mathrm{M}$ solutions, and the stoichiometric concentration of $\mathrm{H}_{2} \mathrm{O}_{2}$, necessary to mineralize completely the 4-NP, was added to the system. The reaction started with the addition of $2.5 \mathrm{~g} \mathrm{~L}^{-1}$ of catalyst. During the experiment, samples of the resulting effluent were collected at different reaction times and prepared for analysis, as described in subsection 2.5. A blank experiment, i.e. without catalyst, was carried out to assess possible non-catalytic oxidation reactions promoted by $\mathrm{H}_{2} \mathrm{O}_{2}$. The adsorption capacity of the catalysts was evaluated by means of pure adsorption experiments using distilled water instead of $\mathrm{H}_{2} \mathrm{O}_{2}$. The experiments were performed in triplicate, and the standard deviation was lower than $5 \%$ in all cases.

\subsection{Analytical methods}

4-NP and the aromatic intermediates were identified and quantified as described elsewhere [25], using a Jasco HPLC system equipped with an UV-VIS detector (UV-2075 Plus), a quaternary gradient pump (PU-
2089 Plus) for solvent delivery and a Kromasil 100-5-C18 column $(15 \mathrm{~cm} \times 4.6 \mathrm{~mm} ; 5 \mu \mathrm{m}$ particle size $)$ working at room temperature. Briefly, small aliquots were periodically withdrawn from the reactor, typically at $0,5,15,30,60,120,240,480$, and $1440 \mathrm{~min}$. In order to stop the reaction, an excess of $\mathrm{Na}_{2} \mathrm{SO}_{3}$ was immediately added to consume the residual $\mathrm{H}_{2} \mathrm{O}_{2}[51,52]$ and the catalyst was removed by filtration. The mobile phase $\left(1 \mathrm{~mL} \mathrm{~min}{ }^{-1}\right)$ consisted of an isocratic method of an A:B (40:60) mixture of 3\% acetic acid and 1\% acetonitrile in methanol (A) and $3 \%$ acetic acid in ultrapure water (B). The absorbance wavelength was adjusted to $318 \mathrm{~nm}$ for the determination of 4$\mathrm{NP}$, and to $277 \mathrm{~nm}$ for the aromatic intermediates. The concentration of carboxylic acids was monitored using a Jasco HPLC system fitted with an YMC - Triart C18 column ( $25 \mathrm{~cm} \times 4.6 \mathrm{~mm} ; 5 \mu \mathrm{m}$ particle size) [25]. The mobile phase $\left(0.6 \mathrm{~mL} \mathrm{~min}^{-1}\right)$ consisted of an isocratic method of an A:B (95:5) mixture of $1 \%$ sulphuric acid in ultrapure water (A) and acetonitrile (B). The UV/VIS detector was set to $210 \mathrm{~nm}$. The TOC content was determined using a Shimadzu TOC-L analyzer. Additionally, two colorimetric methods were used to determine the concentrations of $\mathrm{H}_{2} \mathrm{O}_{2}$ and $\mathrm{Fe}$ in solution by means of UV/VIS spectrophotometry (T70 spectrometer, PG Instruments Ltd.). For the determination of $\mathrm{H}_{2} \mathrm{O}_{2}$, a filtered sample was acidified with a $\mathrm{H}_{2} \mathrm{SO}_{4}$ $0.5 \mathrm{M}$ solution. $0.1 \mathrm{~mL}$ of titanium oxysulfate was added, and the absorbance was measured at $405 \mathrm{~nm}$ [53]. The concentration of Fe species was determined by the $o$-phenanthroline method, according to ISO 6332 [54], using ascorbic acid as reducing agent, and measuring the absorbance at $510 \mathrm{~nm}$.

\section{Results and discussion}

\subsection{Carbon nanotubes characterization}

The $\mathrm{N}_{2}$ adsorption-desorption isotherms of the CNTs (Fig. 1) can be classified as type II according to the IUPAC classification, which are typical of non-porous materials. The hysteresis loop present at high $\mathrm{P} / \mathrm{P}_{0}$ values is associated with capillary condensation occurring in large mesopores, as the spaces between agglomerated CNTs [55]. The $S_{\mathrm{BET}}$ and $\mathrm{V}_{\text {pore }}$ values are summarized in Table 1 . As previously reported [25], the original E30 material consists of very regular multi-walled CNTs, the Ndoped A30 is characterized by a "bamboo-like" structure, and the selectively N-doped E10A20 contains sections of both doped and undoped structures (Fig. S1, Supplementary Material). Both treatments (thermal treatment under inert atmosphere, and oxidation with $\mathrm{HNO}_{3}$ ) lead to higher $\mathrm{S}_{\mathrm{BET}}$ values, which could be related to CNT endcaps opening during the treatments, and a thinning effect of the nanotube walls, as shown in the TEM images (Fig. 2). This effect is especially important for the E30 N sample, which presented the highest $S_{\mathrm{BET}}$ value. Since the other two types of CNTs present a partial (E10A20) or complete (A30) "bamboo-like" structure, the endcaps opening effect is less significant, with the increase in surface area being limited by the existence of small interconnected compartments on the N-doped sections.

TEM images (Fig. 2) show that the regular E30 nanotubes heattreated at $800{ }^{\circ} \mathrm{C}(\mathrm{E} 30 \mathrm{HT})$ present an average external diameter of $c a$. $9.6 \mathrm{~nm}$, whilst those oxidized with nitric acid (E30 N) show a diameter of $c a .8 .5 \mathrm{~nm}$. Although these values are relatively similar, the smaller diameter of $\mathrm{E} 30 \mathrm{~N}$ could indicate a thinning effect of the nanotube walls. In fact, at higher magnification, it was possible to confirm that some nanotubes were damaged by the nitric acid treatment (Fig. S2a, Supplementary Material), occasionally presenting small openings. This effect could be enhanced by existing defects located throughout the walls of the nanotube, which act as nucleation sites for the oxidation and corresponding sidewall etching. Hence, the textural properties, such as $S_{\mathrm{BET}}$, might be significantly impacted, since the access to the interior of some nanotubes would be possible. Interestingly, this could explain why $\mathrm{S}_{\mathrm{BET}}$ of E30 increased from 275 to $652 \mathrm{~m}^{2} \mathrm{~g}^{-1}$ after the nitric acid treatment. With regard to the nanotubes prepared entirely from acetonitrile (A30-series), a slightly larger external diameter than 


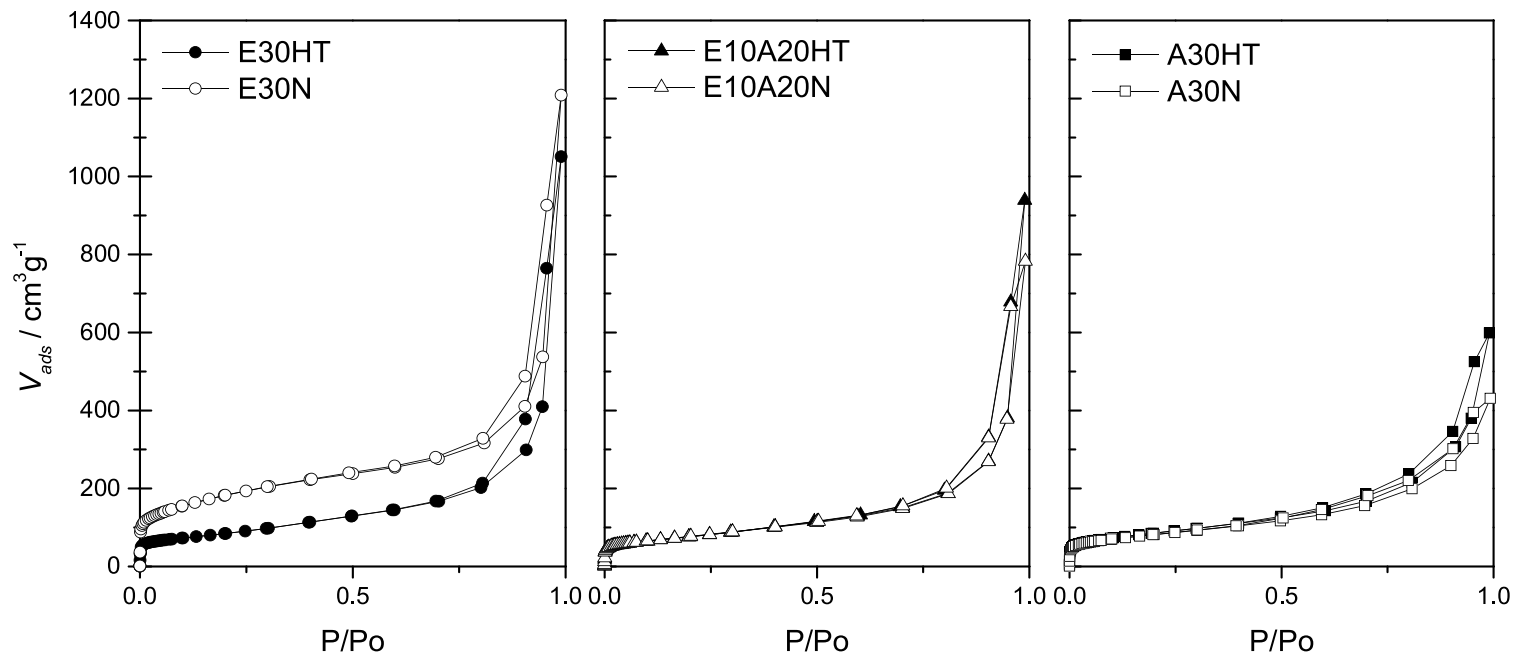

Fig. 1. $\mathrm{N}_{2}$ adsorption-desorption isotherms of the modified CNTs, obtained at $-196{ }^{\circ} \mathrm{C}$.

Table 1

Composition (wt.\%) of CNTs as determined by elemental analysis, and textural properties calculated from $\mathrm{N}_{2}$ adsorption-desorption isotherms.

\begin{tabular}{llllllll}
\hline & $\begin{array}{l}\mathrm{C} \\
(\%)\end{array}$ & $\begin{array}{l}\mathrm{H} \\
(\%)\end{array}$ & $\begin{array}{l}\mathrm{N} \\
(\%)\end{array}$ & $\begin{array}{l}\mathrm{O} \\
(\%)\end{array}$ & $\begin{array}{l}\text { Ash } \\
(\%)\end{array}$ & $\begin{array}{l}\mathrm{S}_{\mathrm{BET}}( \pm 5) \\
\left(\mathrm{m}^{2} \mathrm{~g}^{-1}\right)\end{array}$ & $\begin{array}{l}\mathrm{V}_{\text {pore }}( \pm 0.01) \\
\left(\mathrm{cm}^{3} \mathrm{~g}^{-1}\right)\end{array}$ \\
\hline E30 & 96.7 & 0.3 & - & 1.6 & 1.5 & $275^{\mathrm{a}}$ & $1.92^{\mathrm{a}}$ \\
E30HT & 98.0 & 0.2 & - & 0.7 & 1.1 & 300 & 1.63 \\
E30N & 92.6 & 0.4 & - & 5.4 & 1.5 & 652 & 1.91 \\
E10A20 & 90.1 & 0.5 & 3.0 & 3.1 & 3.2 & $214^{\mathrm{a}}$ & $1.49^{\mathrm{a}}$ \\
E10A20HT & 92.8 & 0.4 & 1.9 & 2.2 & 2.8 & 273 & 1.46 \\
E10A20N & 88.8 & 0.5 & 2.7 & 6.4 & 1.5 & 274 & 1.22 \\
A30 & 82.2 & 0.8 & 5.0 & 7.3 & 4.7 & $212^{\mathrm{a}}$ & $1.11^{\mathrm{a}}$ \\
A30HT & 86.3 & 0.6 & 3.8 & 5.4 & 3.9 & 307 & 0.94 \\
A30N & 80.1 & 0.8 & 4.8 & 11.9 & 2.3 & 291 & 0.68 \\
\hline
\end{tabular}

a Data from [25].

that found for the undoped tubes is observed $(12.6 \mathrm{~nm}$ for A30HT, and $11.7 \mathrm{~nm}$ for A30 N). However, a similar thinning effect as that described before for the E30-series was observed again for the nanotubes that have undergone chemical treatment. Finally, although to a smaller extent (compared to E30 and A30), E10A20 $\mathrm{N}$ also presented a smaller external diameter $(9.8 \mathrm{~nm})$ than E10A20HT $(10.5 \mathrm{~nm})$, confirming a thinning effect from the nitric acid treatment of these materials. It should be noted that, when the nanotubes were initially grown from ethylene (E10A20), the diameter of the N-doped portion was smaller than that observed for the sample grown from only acetonitrile (A30), indicating that these hybrid materials contain two different sections in the same CNT [31] (highlighted in Fig. S2b in Supplementary Material), as opposed to an independent and separate growth of each section. The TEM images also show the presence of encapsulated metal nanoparticles. They are formed during the catalytic CVD synthesis by in situ reduction of the iron oxide catalyst at high temperature, and remain in the CNT structure even after the purification step with 50 vol. $\% \mathrm{H}_{2} \mathrm{SO}_{4}$, conferring magnetic properties to these materials (shown in Fig. S3 in Supplementary Material).

The elemental composition (wt.\%) of the synthesized CNTs is given in Table 1. All samples are mainly composed of carbon, the hydrogen contents being negligible in all cases. Compared to E30-series, there is a decrease in carbon content for the N-doped materials (E10A20 and A30-series), with a corresponding increase of the nitrogen content. Nitrogen and oxygen contents decreased upon heating the CNTs at $800^{\circ} \mathrm{C}$, due to the removal of surface functional groups. On the other

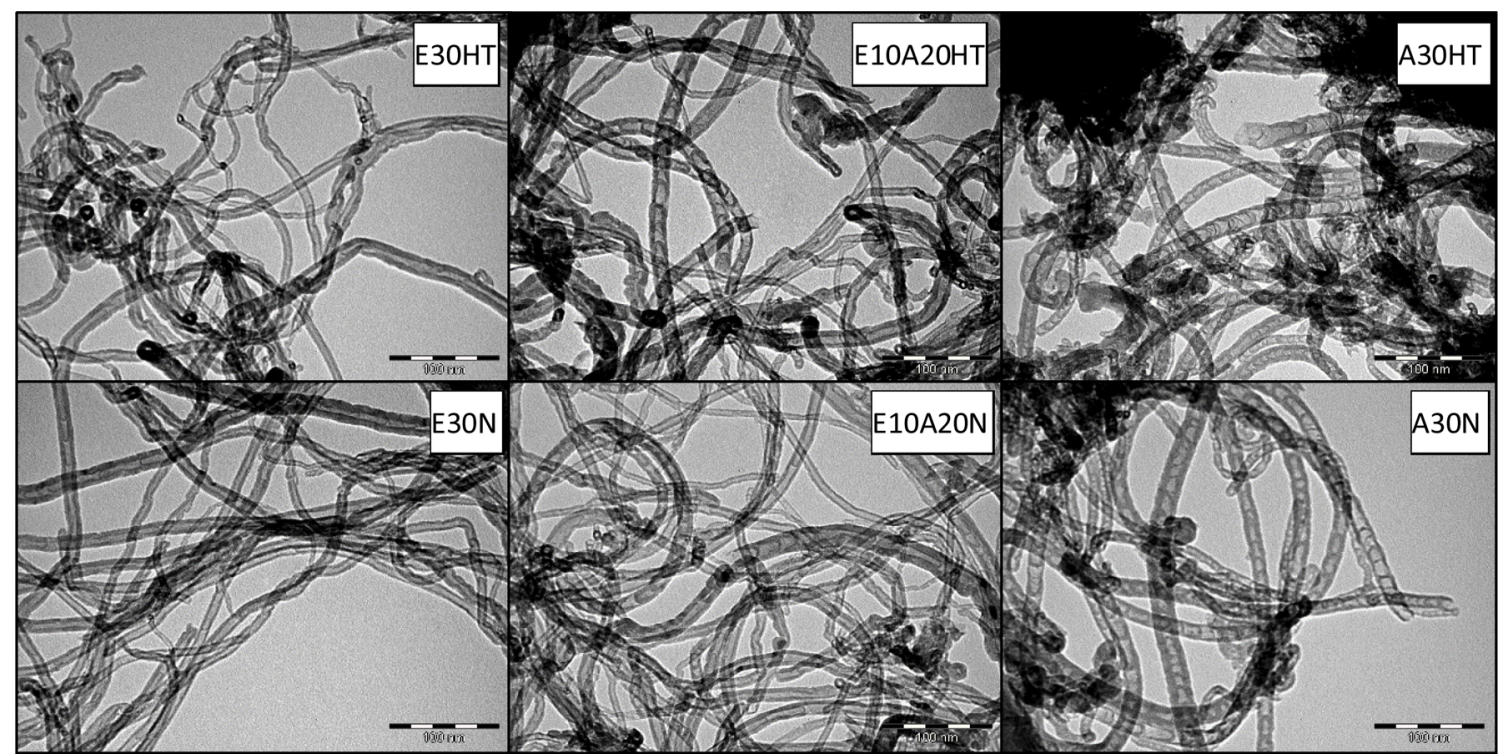

Fig. 2. TEM micrographs of the modified CNTs. 
Table 2

Surface atomic composition, species percentage and corresponding binding energies (in brackets, eV) of the CNTs obtained by XPS.

\begin{tabular}{|c|c|c|c|c|c|c|c|c|c|c|c|c|c|c|c|}
\hline & \multirow[t]{2}{*}{ C (\%) } & \multirow[t]{2}{*}{ O (\%) } & \multirow[t]{2}{*}{ N (\%) } & \multirow[t]{2}{*}{$\mathrm{Fe}(\%)$} & \multicolumn{4}{|l|}{$\mathrm{C}_{1 \mathrm{~s}}(\%)$} & \multicolumn{3}{|l|}{$\mathrm{O}_{1 \mathrm{~s}}(\%)$} & \multicolumn{4}{|l|}{$\mathrm{N}_{1 \mathrm{~s}}(\%)$} \\
\hline & & & & & $C=C$ & $\mathrm{C}-\mathrm{C}$ & $\mathrm{C}-\mathrm{O}$ & $\mathrm{C}=\mathrm{O}$ & $\mathrm{C}=\mathrm{O}$ & $\mathrm{C}-\mathrm{O}$ & $\mathrm{N}-\mathrm{ox}$ & N6 & N5 & NQ & N-ox \\
\hline E30HT & 99.3 & 0.7 & 0.0 & 0.0 & $\begin{array}{l}49 \\
(284.6)\end{array}$ & $\begin{array}{l}30 \\
(285.2)\end{array}$ & $\begin{array}{l}11 \\
(287.7)\end{array}$ & $\begin{array}{l}10 \\
(291.2)\end{array}$ & $\begin{array}{l}29 \\
(530.4)\end{array}$ & $\begin{array}{l}71 \\
(532.6)\end{array}$ & - & - & - & - & - \\
\hline E10A20HT & 98.0 & 1.0 & 0.8 & 0.2 & $\begin{array}{l}46 \\
(284.6)\end{array}$ & $\begin{array}{l}32 \\
(285.2)\end{array}$ & $\begin{array}{l}12 \\
(287.5)\end{array}$ & $\begin{array}{l}10 \\
(291.2)\end{array}$ & $\begin{array}{l}54 \\
(530.6)\end{array}$ & $\begin{array}{l}37 \\
(532.7)\end{array}$ & $\begin{array}{l}9 \\
(534.9)\end{array}$ & $\begin{array}{l}46 \\
(398.7)\end{array}$ & - & $\begin{array}{l}47 \\
(401.2)\end{array}$ & $\begin{array}{l}7 \\
(404.0)\end{array}$ \\
\hline А30HT & 93.0 & 2.3 & 4.1 & 0.6 & $\begin{array}{l}46 \\
(284.6)\end{array}$ & $\begin{array}{l}32 \\
(285.4)\end{array}$ & $\begin{array}{l}13 \\
(287.8)\end{array}$ & $\begin{array}{l}9 \\
(291.2)\end{array}$ & $\begin{array}{l}49 \\
(530.6)\end{array}$ & $\begin{array}{l}38 \\
(532.2)\end{array}$ & $\begin{array}{l}13 \\
(533.8)\end{array}$ & $\begin{array}{l}42 \\
(398.5)\end{array}$ & $\begin{array}{l}9 \\
(400.4)\end{array}$ & $\begin{array}{l}35 \\
(401.1)\end{array}$ & $\begin{array}{l}14 \\
(404.1)\end{array}$ \\
\hline E30N & 96.7 & 3.1 & 0.2 & 0.0 & $\begin{array}{l}48 \\
(284.6)\end{array}$ & $\begin{array}{l}28 \\
(285.2)\end{array}$ & $\begin{array}{l}13 \\
(287.5)\end{array}$ & $\begin{array}{l}11 \\
(291.1)\end{array}$ & $\begin{array}{l}46 \\
(531.6)\end{array}$ & $\begin{array}{l}49 \\
(533.3)\end{array}$ & $\begin{array}{l}5 \\
(535.6)\end{array}$ & - & - & - & - \\
\hline E10A20N & 95.1 & 3.6 & 1.2 & 0.1 & $\begin{array}{l}55 \\
(284.6)\end{array}$ & $\begin{array}{l}19 \\
(285.5)\end{array}$ & $\begin{array}{l}15 \\
(287.3)\end{array}$ & $\begin{array}{l}11 \\
(291.1)\end{array}$ & $\begin{array}{l}48 \\
(531.4)\end{array}$ & $\begin{array}{l}47 \\
(533.3)\end{array}$ & $\begin{array}{l}5 \\
(536.0)\end{array}$ & $\begin{array}{l}36 \\
(398.9)\end{array}$ & - & $\begin{array}{l}34 \\
(401.1)\end{array}$ & $\begin{array}{l}30 \\
(405.1)\end{array}$ \\
\hline A30N & 87.8 & 6.4 & 5.5 & 0.3 & $\begin{array}{l}45 \\
(284.6)\end{array}$ & $\begin{array}{l}31 \\
(285.4)\end{array}$ & $\begin{array}{l}15 \\
(287.9)\end{array}$ & $\begin{array}{l}9 \\
(291.3)\end{array}$ & $\begin{array}{l}51 \\
(531.1)\end{array}$ & $\begin{array}{l}44 \\
(532.9)\end{array}$ & $\begin{array}{l}5 \\
(535.5)\end{array}$ & $\begin{array}{l}35 \\
(399.5)\end{array}$ & $\begin{array}{l}8 \\
(400.4)\end{array}$ & $\begin{array}{l}33 \\
(402.0)\end{array}$ & $\begin{array}{l}24 \\
(405.7)\end{array}$ \\
\hline
\end{tabular}

hand, the oxygen content increased significantly after the nitric acid treatment, due to the incorporation of oxygenated surface groups. The remaining material consisted mainly of Fe particles from the $\mathrm{Fe} / \mathrm{Al}_{2} \mathrm{O}_{3}$ catalyst used in the synthesis of the CNTs, as observed by TEM, which decreases after the modifications, especially after the nitric acid treatment of the $\mathrm{N}$-doped materials.

From the XPS results (Table 2), it can be observed that the surface carbon content of the different CNTs is higher than 95 at.\%, with the exception of the A30 samples, which is lower due to the high concentration of $\mathrm{N}$ and $\mathrm{O}$ heteroatoms ( $c a .93$ and 88 at.\% $\mathrm{C}$ for the heattreated and nitric acid-treated samples, respectively). Given that E30 is prepared from ethylene, there is no nitrogen present, and only a small concentration of oxygen is detected (0.7 at.\%). Nevertheless, after the nitric acid functionalization, the concentration of both oxygen and nitrogen increased to 3.1 and 0.2 at.\%, respectively. Regarding the other samples, the amount of oxygen-containing surface groups increased with the $\mathrm{N}$ content, affecting the type of surface functionalities. It has been shown that ex situ N-doping (i.e., high-temperature thermal treatment under e.g., ammonia) of carbon materials is significantly improved if its surface is functionalized with oxygen species [56]. Interestingly, in this study, we have observed that the oxidation step is much more effective when carried out on $\mathrm{N}$-containing surfaces, based on the higher amount of oxygenated species introduced on A30 compared to E30 ( 3.1 at.\% for E30 N and 6.4 at.\% for A30 N). Given that oxidation first occurs on highly reactive sites [16], the introduction of heteroatoms on the carbon surface is energetically more favorable on defects than on the pristine/undoped surface. This supports the concept that defect-containing surfaces are necessary to introduce high amounts of heteroatoms. Hence, N-containing species can be seen as defects, with theoretical calculations predicting a localization of the unpaired electrons around the nitrogen-defect in the hetero-nanotubes [57], changing the reactivity of the material. Comparing the heat-treated samples with those treated with nitric acid, the amount of nitrogen of the latter is higher. There are two main reasons for this behavior: (i) the nitric acid treatment introduces a small amount of $\mathrm{N}$-containing species on the surface (e.g., 0 at.\% for E30HT and 0.2 at.\% for E30 N), and (ii) for the heat-treated samples, the treatment at $800{ }^{\circ} \mathrm{C}$ removes part of the $\mathrm{N}$-containing groups produced in situ during the CVD synthesis. Hence, only the more stable functionalities, such as N-quaternary and $\mathrm{N}$-pyridinic, remain, whilst N-oxides decompose (Table 2). Small amounts of iron detected by XPS appear only in the N-containing samples, regardless of the treatment (heat-treated or acid-treated), since its concentration in E30 was negligible. Due to the synthesis process, the yield of CNT grown with acetonitrile is significantly lower than that obtained with ethylene [24], leading to higher metal concentrations in the final material. Moreover, given the bamboo-like structure of the N-doped CNTs (Fig. 2), Fe nanoparticles are more easily encapsulated, preventing their removal. This is confirmed by the ash percentages determined by elemental analysis, with N-doped CNTs showing higher values than the E30-series. The decrease in Fe content in the oxidized samples can be explained by the additional dissolution of Fe by nitric acid, perhaps through the opening of some more reactive CNT endcaps during the functionalization step. Nevertheless, given the magnetic properties of the nanoparticles encapsulated inside the CNTs (both undoped and doped, despite the higher concentration in the latter), catalyst separation after the catalytic reaction can be easily achieved using a magnet.

The C1s spectra of the CNTs show the presence of four different carbon bonds. The peak at $\mathrm{BE} \sim 284.6 \mathrm{eV}$ is attributed to the $\mathrm{C}=\mathrm{C}$ bonds corresponding to aromatic $\mathrm{sp}^{2}$ structures, whereas that at $\sim 285.2 \mathrm{eV}$ is assigned to $\mathrm{C}-\mathrm{C}$ ( $\mathrm{sp}^{3}$ carbon species). The peak at $\sim 287.5 \mathrm{eV}$ is typically assigned to $\mathrm{C}-\mathrm{O}$, including epoxy (-O-) and hydroxyl $(\mathrm{O}-\mathrm{H})$ groups, while the peak at $\sim 291.2 \mathrm{eV}$ might be attributed to $\mathrm{C}=\mathrm{O}$, i.e. corresponding to carbonyl $(-\mathrm{C}=\mathrm{O})$, carboxyl $(-\mathrm{COOH})$, and carboxylate $(-\mathrm{COOR})$ groups [58]. On the other hand, the high-resolution 01s spectra of the CNTs were deconvoluted into three components namely, $\mathrm{C}=\mathrm{O}$ (either in carbonyl or in carboxyl groups), $\mathrm{C}-\mathrm{O}$ (assigned to oxygen in phenol/ether groups), and the last component that could correspond to N-oxides or chemisorbed water. Finally, deconvolution of the N1s region of the XPS spectra (Table 2) shows the presence of pyridinic-N (N6), pyrrolic-N (N5), quaternary-N (NQ), and $\mathrm{N}$-oxides (N-ox) for the $\mathrm{N}$-doped materials. As can be seen, no significant differences are observed when comparing the deconvoluted C1s and O1s peaks, with the exception of E30HT, which has no peak associated to $\mathrm{N}$-oxides (this material has no $\mathrm{N}$ in its structure) and presents higher concentration of phenol/ether instead. Larger differences can be observed in the peaks deconvoluted from the N1s region. As explained above, only the most stable groups remain in the materials surface after the heat treatment (NQ and N6), while the acid-treated samples present higher $\mathrm{N}$-ox concentrations.

The decomposition of the different groups on the CNT surface produced the TPD profiles shown in Fig. 3. According to the procedure described elsewhere $[47,59]$, the peaks appearing in the $\mathrm{CO}_{2}$-TPD profiles can be assigned to carboxylic acids (peaks below $450{ }^{\circ} \mathrm{C}$ ), carboxylic anhydrides (between $350-600^{\circ} \mathrm{C}$ ) and lactones (above $600{ }^{\circ} \mathrm{C}$ ), whilst the peaks in the CO-TPD profiles are related to carboxylic anhydrides (between $350-600{ }^{\circ} \mathrm{C}$ ), phenols/ethers $\left(500-800^{\circ} \mathrm{C}\right)$ and carbonyls/quinones $\left(850-950^{\circ} \mathrm{C}\right)$. The difference between the thermally treated and the oxidized samples is demonstrated by the profile shape for each group of materials, as well as the amount of $\mathrm{CO}$ and $\mathrm{CO}_{2}$ released during the analyses (Table 3 ). The incorporation of oxygenated surface groups during nitric acid treatment leads to the release of large amounts of $\mathrm{CO}$ and $\mathrm{CO}_{2}$, whilst the removal of surface functionalities during the thermal treatment results in much lower amounts of these gases. This effect is clearly observed by comparing the amounts of the different functional groups obtained from deconvolution of TPD profiles 


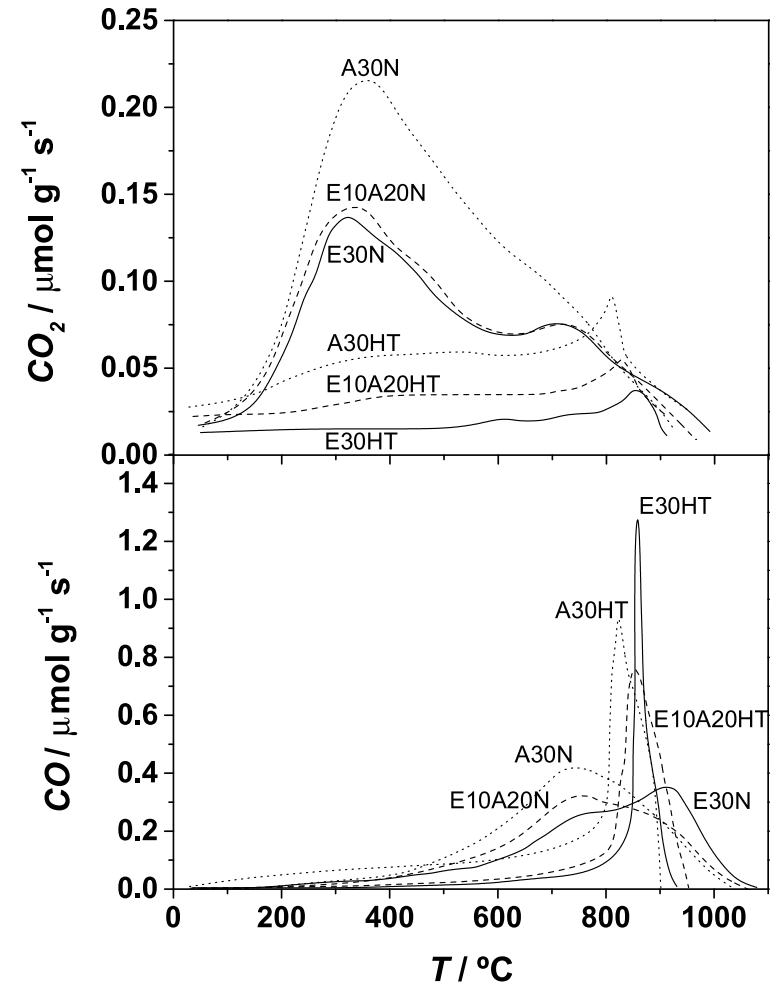

Fig. 3. TPD profiles of the modified CNTs: $\mathrm{CO}_{2}$ (top) and $\mathrm{CO}$ (bottom).

(Table 3). The CNTs treated at $800{ }^{\circ} \mathrm{C}$ show a large signal related to the presence of carbonyl and/or quinone groups, but lower amounts of the other groups. In particular, carboxylic acids, anhydrides and lactones almost disappear in E30HT. The larger amounts of surface functional groups observed in A30HT are due to the larger concentrations present in the original A30 catalyst. On the other hand, the profiles of the samples treated with nitric acid show the presence of large amounts of carboxylic acids and anhydrides. With the exception of the carbonyl/ quinone peak, which seems to be preferentially present on the undoped samples, all other surface groups are present in higher concentrations on the $\mathrm{N}$-doped materials. Moreover, the sharp peaks observed at $\sim 850^{\circ} \mathrm{C}$ in the thermally treated samples can be attributed to the presence of $\mathrm{Fe}$. These sharp peaks are not found in the oxidized samples, since, as was observed by XPS, the treatment with nitric acid removes the remaining Fe.

The $\mathrm{pH}_{\mathrm{PZC}}$ of the modified CNTs (Table 3 ) is consistent with the results of both XPS and TPD analyses, since the heat treatment of the materials under inert atmosphere at $800^{\circ} \mathrm{C}$ leads to neutral or basic surfaces, while oxidation with nitric acid results in materials with a more acidic surface.

The incorporation of oxygen- and nitrogen-containing functionalities onto the CNTs modifies their hydrophilic properties, which were determined from water contact angle measurements obtained from the corresponding buckypapers. In Fig. 4, it can be observed that the heattreated CNTs were less hydrophilic than those treated with nitric acid, which should be ascribed to the increased surface content of oxygen and nitrogen after oxidation, as shown by XPS and TPD. It is noteworthy the low contact angle of A30HT (i.e., $18 \pm 2^{\circ}$ ), which should be due to the 2.3 at. $\% \mathrm{O}_{\mathrm{XPS}}$ and 4.1 at.\% $\mathrm{N}_{\mathrm{XPS}}$ even after the thermal treatment at $800{ }^{\circ} \mathrm{C}$. In general, the contact angles decreased as follows: $\mathrm{E} 30>\mathrm{E} 10 \mathrm{~A} 20>\mathrm{A} 30$, regardless of whether the samples were heattreated or oxidized. Thus, the E30HT sample presented a moderate hydrophobicity, with the highest contact angle (i.e., $59 \pm 2^{\circ}$ ), while the A30 N sample can be considered highly hydrophilic, with a contact angle as low as $9 \pm 1^{\circ}$.

\subsection{Catalytic performance in CWPO}

In a previous study, the role of N-doping in CNTs used in the CWPO process was studied [25]. The aim of the current work is to study the activity of these CNTs after different surface modifications, in which there will be a competition between the effect caused by the N-doping, and the effect caused by the treatment (heat treatment or oxidation).

Screening experiments were carried out to assess the performances of the different CNT samples during the CWPO of highly concentrated 4-NP solutions. The removal of 4-NP by CWPO and the decomposition of $\mathrm{H}_{2} \mathrm{O}_{2}$ observed during 24-hour experiments are shown in Fig. 5. The curves corresponding to the non-modified CNTs from a previous work [25] have been included for comparison purposes (represented in grey).

It is expected that the adsorption of 4-NP, a weak acid, is favored on materials with a basic surface. Using the heat-treated materials, with a $\mathrm{pH}_{\text {PZC }}$ significantly higher than the working $\mathrm{pH}$ (3 in all cases), 4-NP partially dissociates to its anionic form, thus favoring the electrostatic interaction between adsorbent and adsorptive. On the other hand, it has been reported that the adsorption of molecules such as 4-NP on hydrophilic surfaces (e.g., $\mathrm{HNO}_{3}$ treated samples) is lower due to the formation of water molecule clusters on the carbon porous structure, resulting in pore blockages (solvent effect) [60]. Due to this phenomenon, some pores may be inaccessible to the formed 4-NP-water aggregates. Hence, thermally-treated samples are expected to show a much better behavior in the CWPO of 4-NP than oxidized ones.

As observed in Fig. 5, the catalysts synthesized from the completely $\mathrm{N}$-doped sample (A30HT and A30 N) promote a fast decomposition of $\mathrm{H}_{2} \mathrm{O}_{2}$, resulting in a poor 4-NP removal. For sample A30, the limited CWPO performance was attributed to the fast decomposition of $\mathrm{H}_{2} \mathrm{O}_{2}$ into non-reactive species $\left(\mathrm{H}_{2} \mathrm{O}\right.$ and $\left.\mathrm{O}_{2}\right)$ promoted by the $\mathrm{N}$-doped hydrophilic surfaces [25]. Nevertheless, the conversion of 4-NP is significantly improved for the surface-modified samples (heat-treated and nitric acid-treated), despite the fast $\mathrm{H}_{2} \mathrm{O}_{2}$ decomposition observed in both cases. As observed for A30, both A30HT and especially A30 N have hydrophilic character, and contain large concentrations of electron donating groups (as evidenced by XPS), explaining the fast decomposition of $\mathrm{H}_{2} \mathrm{O}_{2}$. The activity improvement observed for $\mathrm{A} 30 \mathrm{~N}$, when compared to $\mathrm{A} 30$, could be related to the reactivity generated inside the

Table 3

Surface oxygenated functionalities by TPD analyses, and $\mathrm{pH}_{\mathrm{PZC}}$ of the original and modified CNTs.

\begin{tabular}{|c|c|c|c|c|c|c|c|c|}
\hline Sample & $\begin{array}{l}\mathrm{CO}_{2} \\
\left(\mu \mathrm{mol} \mathrm{g}{ }^{-1}\right)\end{array}$ & $\begin{array}{l}\mathrm{CO} \\
\left(\mu \mathrm{mol} \mathrm{g}{ }^{-1}\right)\end{array}$ & $\begin{array}{l}\text { carboxylic } \\
\left(\mu \mathrm{mol} \mathrm{g}{ }^{-1}\right)\end{array}$ & $\begin{array}{l}\text { lactone } \\
\left(\mu \mathrm{mol} \mathrm{g}{ }^{-1}\right)\end{array}$ & $\begin{array}{l}\text { anhydride } \\
\left(\mu \mathrm{mol} \mathrm{g}{ }^{-1}\right)\end{array}$ & $\begin{array}{l}\text { phenol/ether } \\
\left(\mu \mathrm{mol} \mathrm{g}{ }^{-1}\right)\end{array}$ & $\begin{array}{l}\text { carbonyl/quinone } \\
\left(\mu \mathrm{mol} \mathrm{g}^{-1}\right)\end{array}$ & $\mathrm{pH}_{\mathrm{PZC}}$ \\
\hline E30 & 364 & 864 & 49 & 40 & 40 & 102 & 552 & 6.9 \\
\hline A30 & 510 & 930 & 61 & 62 & 200 & 605 & 348 & 6.3 \\
\hline E30HT & 173 & 427 & 5 & 15 & 16 & 141 & 401 & 8.1 \\
\hline E10A20HT & 306 & 699 & 25 & 17 & 30 & 189 & 424 & 7.8 \\
\hline А30HT & 519 & 1416 & 55 & 59 & 132 & 186 & 340 & 7.2 \\
\hline E30N & 691 & 921 & 261 & 238 & 192 & 637 & 318 & 2.2 \\
\hline E10A20N & 714 & 1075 & 256 & 236 & 216 & 831 & 233 & 2.2 \\
\hline $\mathrm{A} 30 \mathrm{~N}$ & 1056 & 1472 & 264 & 243 & 501 & 982 & 219 & 2.0 \\
\hline
\end{tabular}




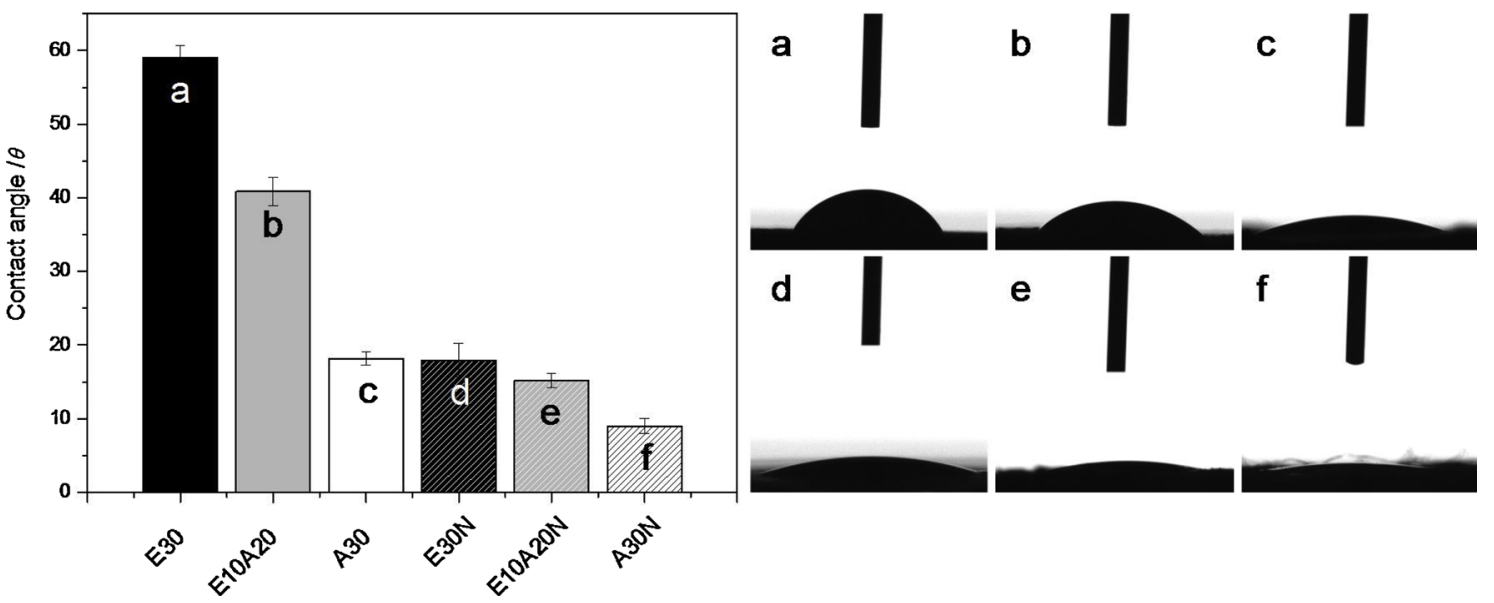

Fig. 4. Contact angle measurements determined for buckypapers prepared with different CNTs: Heat-treated (a-c) and nitric acid-treated (d-f).

opened nanotubes, allowing $\mathrm{HO}^{\circ}$ to react with the 4-NP molecules adsorbed in the close proximity, before the radicals disappear by scavenging effects [43].

With regard to the catalysts derived from E30, E30HT decomposed $\mathrm{H}_{2} \mathrm{O}_{2}$ at a moderate rate, resulting in the complete conversion of 4-NP. The moderate hydrophobicity of E30 has been reported to favor the controllable and efficient decomposition of $\mathrm{H}_{2} \mathrm{O}_{2}$ into highly reactive $\mathrm{HO}^{\circ}$ radicals [25]. The same moderate hydrophobicity has been found for E30HT, favoring the decomposition of $\mathrm{H}_{2} \mathrm{O}_{2}$ into $\mathrm{HO}^{\circ}$, thus showing that E30HT has a high catalytic activity for the 4-NP degradation. As will be seen below (Table 4), in comparison with the other catalysts, the efficiency of the $\mathrm{H}_{2} \mathrm{O}_{2}$ when using E30HT is clearly superior. On the other hand, when treated with nitric acid (increased concentration of oxygen functionalities, viz. lactones, phenols, carboxylic acids and anhydrides, increasing the catalyst surface hydrophilicity - a contact angle similar to that of A30HT was determined, $c a .18^{\circ}$ ) this sample (E30 N) promoted a faster $\mathrm{H}_{2} \mathrm{O}_{2}$ decomposition, which slowed down the CWPO of 4-NP. Despite the fast decomposition of $\mathrm{H}_{2} \mathrm{O}_{2}$ with $\mathrm{E} 30 \mathrm{~N}$, the higher specific surface area of this material $\left(650 \mathrm{~m}^{2} \mathrm{~g}^{-1}\right)$ favored the reaction between the $\mathrm{HO}$ and the 4-NP molecules, allowing the reaction to occur in the internal cylindrical mesopores (confinement effect).

As already reported, the selectively N-doped E10A20 sample, consisting of hybrid structures containing both undoped and $\mathrm{N}$-doped sections, has an intermediate behavior, showing an intermediate $\mathrm{H}_{2} \mathrm{O}_{2}$ decomposition rate and 4-NP removal [25]. The thermal treatment (E10A20HT) improved the 4-NP conversion, showing a behavior similar to E30 and E30HT, removing 99\% of the pollutant after $8 \mathrm{~h}$. Nevertheless, the $\mathrm{HNO}_{3}$ treatment (E10A20 N) hindered the $\mathrm{H}_{2} \mathrm{O}_{2}$ decomposition and, consequently, the 4-NP removal (conversion of $60 \%$ ). It is well accepted that basic active sites are responsible for the generation of $\mathrm{HO}{ }^{-}$radicals at the carbon surface, which include basic surface groups such as quinones, chromenes, and pyrones, as well as delocalized $\pi$ electrons on carbon basal planes [40,61].

In general, materials with higher microporosities and surface densities of available electrons yield higher $\mathrm{H}_{2} \mathrm{O}_{2}$ decomposition rates [41]. Several authors have reported that basic carbon materials lead to higher $\mathrm{H}_{2} \mathrm{O}_{2}$ decomposition rates, whilst acidic carbons exhibit a limited activity in the decomposition of $\mathrm{H}_{2} \mathrm{O}_{2}[40,42,62,63]$. The presence of surface acidic groups in E10A20 N, demonstrated by XPS and TPD analyses, as well as the $\mathrm{pH}_{\mathrm{PZC}}$ shown by this material, explains its decreased ability to decompose $\mathrm{H}_{2} \mathrm{O}_{2}$. Despite this more controllable decomposition, the same acidity hinders the CWPO reaction, since, as explained before, the adsorption of the 4-NP molecules on the material's hydrophilic surface is hindered.

Table 4 presents the conversions (X) of 4-NP, total organic carbon (TOC), and $\mathrm{H}_{2} \mathrm{O}_{2}$ achieved for each catalyst, as well as the
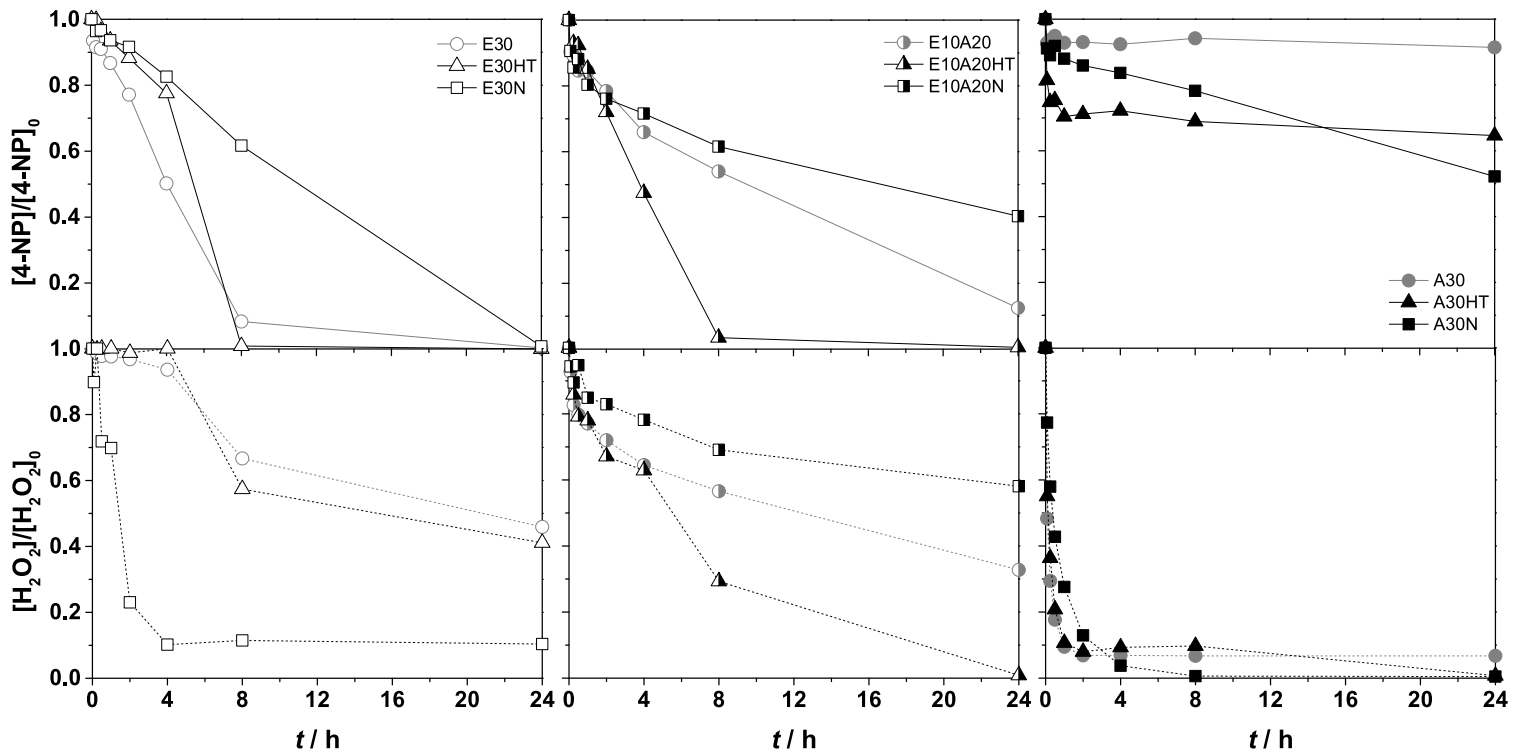

Fig. 5. Concentration evolution of 4-NP (top) and $\mathrm{H}_{2} \mathrm{O}_{2}$ (bottom) during the CWPO experiments (normalized by the initial concentrations). 
Table 4

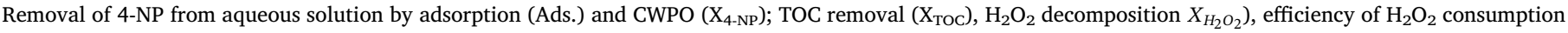
$\left(\eta_{\mathrm{H}_{2} \mathrm{O}_{2}}\right)$, Fe leaching, and reaction byproducts resulting from the CWPO experiments; results after $24 \mathrm{~h}$.

\begin{tabular}{|c|c|c|c|c|c|c|c|c|}
\hline & $\begin{array}{l}\text { Ads. } \\
(\%)\end{array}$ & $\begin{array}{l}\mathrm{X}_{4-\mathrm{NP}} \\
(\%)\end{array}$ & $\begin{array}{l}X_{\mathrm{H}_{2} \mathrm{O}_{2}} \\
(\%)\end{array}$ & $\begin{array}{l}\mathrm{X}_{\mathrm{TOC}} \\
(\%)\end{array}$ & $\eta_{\mathrm{H}_{2} \mathrm{O}_{2}}$ & $\begin{array}{l}\mathrm{Fe} \\
\left(\mathrm{mg} \mathrm{L}^{-1}\right)\end{array}$ & $\begin{array}{l}\text { Saromatics }^{\mathrm{a}} \\
\left(\mathrm{mgCL}^{-1}\right)\end{array}$ & $\begin{array}{l}\sum \text { acids }^{\mathrm{b}} \\
\left(\mathrm{mgC} \mathrm{L}^{-1}\right)\end{array}$ \\
\hline E30 & 6 & 100 & 54 & 54 & 100 & 1.35 & 33.1 & $2,169.5$ \\
\hline E10A20 & 7 & 88 & 67 & 44 & 66 & 2.61 & 355.2 & $1,325.7$ \\
\hline A30 & 1 & 9 & 93 & 18 & 19 & 3.89 & 21.0 & 359.0 \\
\hline E30HT & 8 & 100 & 59 & 59 & 100 & 1.46 & 3.4 & $1,076.6$ \\
\hline E10A20HT & 7 & 99 & 99 & 48 & 48 & 4.56 & 140.2 & 786.9 \\
\hline А30HT & 4 & 35 & 99 & 22 & 22 & 4.38 & 155.0 & 166.0 \\
\hline E30N & 14 & 99 & 90 & 54 & 60 & 0.54 & 36.8 & $1,480.4$ \\
\hline E10A20N & 7 & 60 & 42 & 13 & 31 & 1.42 & 460.7 & 220.3 \\
\hline A30N & 8 & 48 & 100 & 2 & 2 & 0.15 & 73.9 & 74.5 \\
\hline
\end{tabular}

a Sum of mgC in hydroquinone, 1,4-benzoquinone, catechol and 4-nitrocatechol.

b Sum of mgC in oxalic acid, formic acid, malic acid, malonic acid, acetic acid and maleic acid.

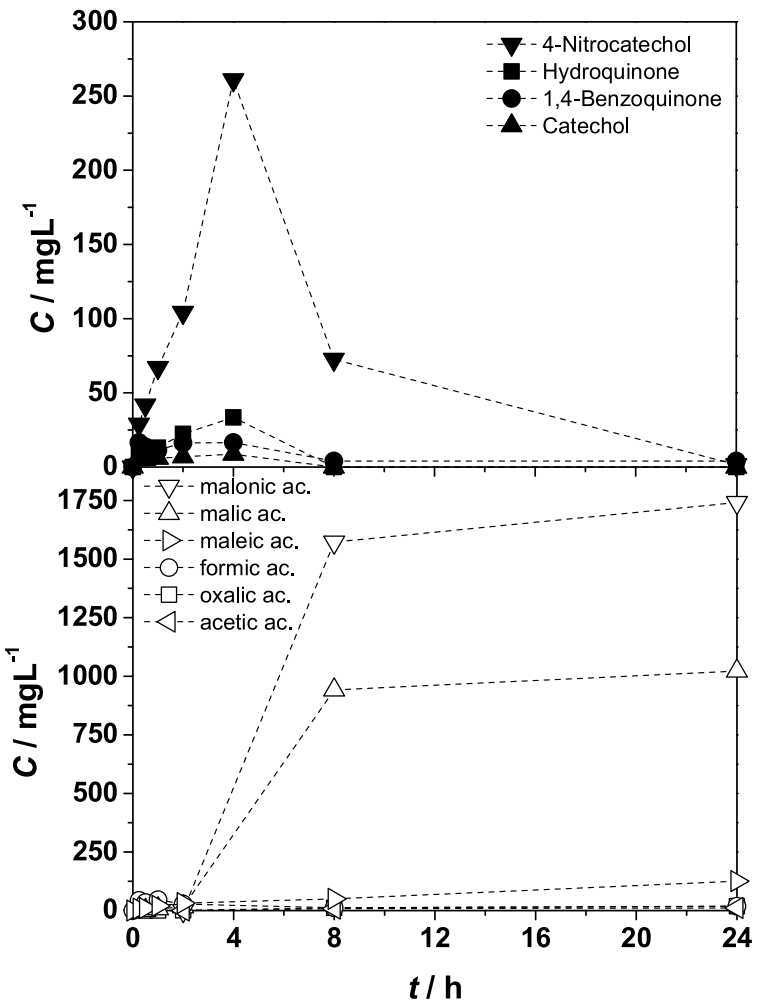

Fig. 6. Concentration ( $\mathrm{mg} \mathrm{L}^{-1}$ ) evolution with time (h) for the different compounds resulting from the CWPO of 4-NP using E30HT.

concentration of Fe leached into the solution, the efficiency of $\mathrm{H}_{2} \mathrm{O}_{2}$ consumption $\left(\eta_{\mathrm{H}_{2} \mathrm{O}_{2}}\right)$, defined as the TOC removal ( $X_{T O C}$ in \%) per unit of $\mathrm{H}_{2} \mathrm{O}_{2}$ decomposed $\left(\mathrm{X}_{\mathrm{H}_{2} \mathrm{O}_{2}}\right.$ in \%), and the reaction byproducts obtained after $24 \mathrm{~h}$ of reaction. As observed in Fig. 5, the removal of surface functionalities by heating the CNT samples at $800^{\circ} \mathrm{C}$ improved their activity towards CWPO, evaluated in terms of 4-NP and TOC conversion. In particular, E30HT and E10A20HT were able to remove ca. $100 \%$ of 4-NP. Despite the high conversion obtained with E30 N, $14 \%$ corresponds to pure adsorption of the pollutant molecules on the catalyst surface. In general, TOC conversion is higher with the thermally treated materials. Moreover, the highly efficient decomposition of $\mathrm{H}_{2} \mathrm{O}_{2}$ into $\mathrm{HO}^{\circ}$ with E30HT results in a TOC conversion of $c a .60 \%$, with $\sim 3 \mathrm{mgC} \mathrm{L}^{-1}$ of aromatic byproducts and $1 \mathrm{gC} \mathrm{L}^{-1}$ of organic acids being detected after $24 \mathrm{~h}$. Fig. 6 shows the time-evolution of the different compounds identified during the CWPO of 4-NP for E30HT; the concentrations of the aromatic byproducts follow the sequence: 4-nitrocatechol $>$ hydroquinone $>1$,4-benzoquinone $>$ catechol, which is consistent with the reaction mechanisms published for this reaction [32,64-66]. These intermediates disappear almost completely after $24 \mathrm{~h}$, increasing the concentration of low-molecular-weight carboxylic acids (mainly malonic and malic acids). E10A20HT shows an activity similar to E30HT. Despite that, the efficiency of the $\mathrm{H}_{2} \mathrm{O}_{2}$ consumption decreased by half, with the Fe leaching into the solution possibly contributing to the activity. This significant Fe leaching was also observed with A30HT. However, in this case, the fast and inefficient decomposition of $\mathrm{H}_{2} \mathrm{O}_{2}$ slowed down the reaction, resulting in lower TOC conversion and byproducts concentration. Regarding the CNTs treated with $\mathrm{HNO}_{3}$, as already observed for the heat-treated ones, when the $\mathrm{N}$ content increased (E30N $<$ E10A20 N $<$ A30N), the efficiency of $\mathrm{H}_{2} \mathrm{O}_{2}$ consumption decreased and so did the TOC conversion.

\section{Conclusions}

The surface chemistry of carbon nanotubes with different N-doping and hydrophilicity grade (E30, undoped and moderately hydrophobic; A30, N-doped and hydrophilic; E10A20, selectively N-doped, with both hydrophilic and hydrophobic sections) plays an important role in their performance during the catalytic wet peroxide oxidation (CWPO) of highly concentrated solutions of 4-nitrophenol (4-NP, $5 \mathrm{~g} \mathrm{~L}^{-1}$ ). The removal of surface functionalities by heat treatment of the CNTs under inert atmosphere at $800{ }^{\circ} \mathrm{C}$ produced the samples CNT-HT, for which the interaction between the 4-NP molecules and the CNT surface is favored. Among the CNT-HT samples, the more hydrophobic materials (E30HT and E10A20HT) promote a controllable $\mathrm{H}_{2} \mathrm{O}_{2}$ decomposition into $\mathrm{HO}^{-}$radicals, being able to remove $c a .100 \%$ of $4-\mathrm{NP}$ after $8 \mathrm{~h}$ of operation. On the contrary, the hydrophilic A30HT promotes the fast $\mathrm{H}_{2} \mathrm{O}_{2}$ decomposition into non-reactive species, resulting in a poor pollutant removal. The oxidation of the CNTs by nitric acid produced hydrophilic samples (CNT-N) with opened ends, in which the decomposition of $\mathrm{H}_{2} \mathrm{O}_{2}$ is fast. Nevertheless, the reactivity generated inside the opened nanotubes favored the reaction between the $\mathrm{HO}^{-}$radicals and the 4-NP molecules in the internal cylindrical mesopores, allowing the reaction to occur before the radicals disappear by scavenging effects.

\section{Acknowledgments}

This work is a result of project “AIProcMat@N2020 - Advanced Industrial Processes and Materials for a Sustainable Northern Region of Portugal 2020", with the reference NORTE-01-0145-FEDER-000006, supported by NORTE 2020, under the Portugal 2020 Partnership Agreement, through the ERDF and of Project Associate Laboratory LSRE-LCM - UID/EQU/50020/2019 - funded by national funds through FCT/MCTES (PIDDAC). M. Martín Martínez acknowledges the postdoc grant 2017-T2/AMB-5668 from Comunidad de Madrid, Programme 
"Atracción de talento investigador". B. Machado acknowledges the exploratory project under FCT Investigator Programme (ref. IF/00301/ 2015) with the financial support of FCT/MCTES through national funds (PIDDAC). S. Morales Torres acknowledges the financial support from University of Granada (Reincorporación Plan Propio).

\section{Appendix A. Supplementary data}

Supplementary data associated with this article can be found, in the online version, at doi:10.1016/j.cattod.2019.03.014.

\section{References}

[1] P. Serp, J.L. Figueiredo (Eds.), Carbon Materials For Catalysis, John Wiley \& Sons, Inc, 2009.

[2] F. Rodríguez-Reinoso, Carbon 36 (1998) 159-175.

[3] P. Serp, M. Corrias, P. Kalck, Appl. Catal. A 253 (2003) 337-358.

[4] C. Moreno-Castilla, F.J. Maldonado-Hódar, Carbon 43 (2005) 455-465.

[5] B.F. Machado, P. Serp, Catal. Sci. Technol. 2 (2012) 54-75.

[6] V.N. Popov, Mater. Sci. Eng. R 43 (2004) 61-102.

[7] G. Ovejero, J.L. Sotelo, M.D. Romero, A. Rodríguez, M.A. Ocaña, G. Rodríguez, J. García, Ind. Eng. Chem. Res. 45 (2006) 2206-2212.

[8] T.W. Ebbesen, P.M. Ajayan, Nature 358 (1992) 220.

[9] T. Guo, P. Nikolaev, A.G. Rinzler, D. Tomanek, D.T. Colbert, R.E. Smalley, J. Phys. Chem. 99 (1995) 10694-10697.

[10] O. Smiljanic, B.L. Stansfield, J. Dodelet, A. Serventi, S. Désilets, Chem. Phys. Lett. 356 (2002) 189-193.

[11] M. José-Yacamán, M. Miki-Yoshida, L. Rendón, J.G. Santiesteban, Appl. Phys. Lett. 62 (1993) 202-204.

[12] M. Kulmar, Y. Ando, J. Nanosci. Nanotechnol. 10 (2010) 3739-3758.

[13] S. Mallakpour, S. Soltanian, RSC Adv. 6 (2016) 109916-109935.

[14] A.K. Deb, C.C. Chusuei, Aqueous solution surface chemistry of carbon nanotubes, in: Satoru Suzuki (Ed.), Physical and Chemistry Properties of Carbon Nanotubes, Intech Open, 2013, pp. 275-293.

[15] R.P. Rocha, O.S. Soares, J.L. Figueiredo, M.F. Pereira, C 2 (2016) 1-18.

[16] I. Gerber, M. Oubenali, R. Bacsa, J. Durand, A. Gonçalves, M.F.R. Pereira, F. Jolibois, L. Perrin, R. Poteau, P. Serp, Chem. Eur. J. 17 (2011) 11467-11477.

[17] R.P. Rocha, A.M.T. Silva, S.M.M. Romero, M.F.R. Pereira, J.L. Figueiredo, Appl. Catal. B 147 (2014) 314-321.

[18] E.N. Nxumalo, P.J. Letsoalo, L.M. Cele, N.J. Coville, J. Organomet. Chem. 695 (2010) 2596-2602.

[19] R.P. Rocha, J.P.S. Sousa, A.M.T. Silva, M.F.R. Pereira, J.L. Figueiredo, Appl. Catal. B 104 (2011) 330-336.

[20] H.P. Boehm, Catalytic properties of nitrogen-containing carbons, in: P. Serp, J.L. Figueiredo (Eds.), Carbon Materials for Catalysis, John Wiley \& Sons, Inc., 2008, pp. 219-265.

[21] J.L. Figueiredo, M.F.R. Pereira, Catal. Today 150 (2010) 2-7.

[22] O. Stephan, P.M. Ajayan, C. Colliex, P. Redlich, J.M. Lambert, P. Bernier, P. Lefin, Science 266 (1994) 1683.

[23] P. Ayala, R. Arenal, M. Rümmeli, A. Rubio, T. Pichler, Carbon 48 (2010) 575-586.

[24] A.D. Purceno, B.F. Machado, A.P.C. Teixeira, T.V. Medeiros, A. Benyounes, J. Beausoleil, H.C. Menezes, Z.L. Cardeal, R.M. Lago, P. Serp, Nanoscale 7 (2015) 294-300.

[25] M. Martin-Martinez, R.S. Ribeiro, B.F. Machado, P. Serp, S. Morales-Torres, A.M.T. Silva, J.L. Figueiredo, J.L. Faria, H.T. Gomes, ChemCatChem 8 (2016) 2068-2078.

[26] A.L. Mihalchik, W. Ding, D.W. Porter, C. McLoughlin, D. Schwegler-Berry, J.D. Sisler, A.B. Stefaniak, B.N. Snyder-Talkington, R. Cruz-Silva, M. Terrones, S. Tsuruoka, M. Endo, V. Castranova, Y. Qian, Toxicology 333 (2015) 25-36.

[27] K.V. Voitko, R.L.D. Whitby, V.M. Gun'ko, O.M. Bakalinska, M.T. Kartel, K. Laszlo, A.B. Cundy, S.V. Mikhalovsky, J. Colloid Interface Sci. 361 (2011) 129-136.

[28] K. Voitko, A. Tóth, E. Demianenko, G. Dobos, B. Berke, O. Bakalinska, A. Grebenyuk, E. Tombácz, V. Kuts, Y. Tarasenko, M. Kartel, K. László, J. Colloid Interface Sci. 437 (2015) 283-290.
[29] F. Peng, L. Zhang, H. Wang, P. Lv, H. Yu, Carbon 43 (2005) 2405-2408.

[30] H.T. Gomes, S.M. Miranda, M.J. Sampaio, J.L. Figueiredo, A.M.T. Silva, J.L. Faria, Appl. Catal. B 106 (2011) 390-397.

[31] A. Benyounes, F. Ouanji, S. Louisia, M. Ziyad, P. Serp, M. Kacimi, Catal. Today 301 (2018) 183-190.

[32] M. Martin-Martinez, M.F.F. Barreiro, A.M.T. Silva, J.L. Figueiredo, J.L. Faria, H.T. Gomes, Appl. Catal. B 219 (2017) 372-378.

[33] M. Martin-Martinez, S. Álvarez-Torrellas, J. García, A.M.T. Silva, J.L. Faria, H.T. Gomes, Catal. Today 313 (2018) 20-25.

[34] L.F. Liotta, M. Gruttadauria, G. Di Carlo, G. Perrini, V. Librando, J. Hazard. Mater. 162 (2009) 588-606.

[35] R.S. Ribeiro, A.M.T. Silva, J.L. Figueiredo, J.L. Faria, H.T. Gomes, Appl. Catal. B 187 (2016) 428-460.

[36] E.V. Rokhina, J. Virkutyte, Crit. Rev. Environ. Sci. Technol. 41 (2010) 125-167.

[37] G. Calleja, J.A. Melero, F. Martinez, R. Molina, Water Res. 39 (2005) 1741-1750.

[38] A. Rey, M. Faraldos, J.A. Casas, J.A. Zazo, A. Bahamonde, J.J. Rodriguez, Appl. Catal. B 86 (2009) 69-77.

[39] A. Onda, Y. Suzuki, S. Takemasa, K. Kajiyoshi, K. Yanagisawa, J. Mater. Sci. 43 (2008) 4230-4235.

[40] R.S. Ribeiro, A.M.T. Silva, J.L. Figueiredo, J.L. Faria, H.T. Gomes, Carbon 62 (2013) 97-108.

[41] A. Rey, J.A. Zazo, J.A. Casas, A. Bahamonde, J.J. Rodriguez, Appl. Catal. A 402 (2011) 146-155.

[42] V.P. Santos, M.F.R. Pereira, P.C.C. Faria, J.J.M. Órfão, J. Hazard. Mater. 162 (2009) 736-742.

[43] M. Soria-Sánchez, E. Castillejos-López, A. Maroto-Valiente, M.F.R. Pereira, J.J.M. Órfão, A. Guerrero-Ruiz, Appl. Catal. B 121-122 (2012) 182-189.

[44] R.S. Ribeiro, N.A. Fathy, A.A. Attia, A.M.T. Silva, J.L. Faria, H.T. Gomes, Chem. Eng. J. 195-196 (2012) 112-121.

[45] S. Brunauer, P.H. Emmett, E. Teller, J. Am. Chem. Soc. 60 (1938) 309-319.

[46] E.P. Barrett, L.G. Joyner, P.P. Halenda, J. Am. Chem. Soc. 73 (1951) 373-380.

[47] J.L. Figueiredo, M.F.R. Pereira, M.M.A. Freitas, J.J.M. Órfão, Carbon 37 (1999) 1379-1389.

[48] G. Newcombe, R. Hayes, M. Drikas, Colloids Surf. A 78 (1993) 65-71.

[49] J.J.M. Órfão, A.I.M. Silva, J.C.V. Pereira, S.A. Barata, I.M. Fonseca, P.C.C. Faria, M.F.R. Pereira, J. Colloid Interface Sci. 296 (2006) 480-489.

[50] S. Morales-Torres, T.L.S. Silva, L. Pastrana-Martinez, A.T.S.C. Brandao, J.L. Figueiredo, A.M.T. Silva, Phys. Chem. Chem. Phys. 16 (2014) 12237-12250.

[51] F. Duarte, F.J. Maldonado-Hódar, L.M. Madeira, Appl. Catal. B 103 (2011) $109-115$.

[52] J.H. Ramirez, C.A. Costa, L.M. Madeira, G. Mata, M.A. Vicente, M.L. RojasCervantes, A.J. López-Peinado, R.M. Martín-Aranda, Appl. Catal. B 71 (2007) 44-56.

[53] W.C. Ketchie, Y. Fang, M.S. Wong, M. Murayama, R.J. Davis, J. Catal. 250 (2007) 94-101.

[54] ISO 6332:1988, 1988.

[55] K.S.W. Sing, D.H. Everett, R.A.W. Haul, L. Moscou, R.A. Pierotti, J. Rouquerol, T. Siemieniewska, Pure Appl. Chem. 57 (1985) 603-619.

[56] P. Serp, B.F. Machado, B.F. Machado, Doped nanostructured carbon materials as catalysts, in: P. Serp (Ed.), Nanostructured Carbon Materials for Catalysis, RSC, 2015, pp. 268-311.

[57] A.H. Nevidomskyy, G. Csányi, M.C. Payne, Phys. Rev. Lett. 91 (2003) 105502.

[58] D. Luo, G. Zhang, J. Liu, X. Sun, J. Phys. Chem. C 115 (2011) 11327-11335.

[59] J.L. Figueiredo, M.F.R. Pereira, M.M.A. Freitas, J.J.M. Órfão, Ind. Eng. Chem. Res. 46 (2007) 4110-4115.

[60] A. Morsli, A. Benhamou, J. Basly, M. Baudu, Z. Derriche, RSC Adv. 5 (2015) 41631-41638.

[61] C.A. Leon y Leon, J.M. Solar, V. Calemma, L.R. Radovic, Carbon 30 (1992) 797-811.

[62] F. Lücking, H. Köser, M. Jank, A. Ritter, Water Res. 32 (1998) 2607-2614.

[63] L.B. Khalil, B.S. Girgis, T.A. Tawfik, J. Chem. Technol. Biotechnol. 76 (2001) 1132-1140.

[64] R.S. Ribeiro, A.M.T. Silva, L.M. Pastrana-Martínez, J.L. Figueiredo, J.L. Faria, H.T. Gomes, Catal. Today 249 (2015) 204-212.

[65] R.S. Ribeiro, A.M.T. Silva, P.B. Tavares, J.L. Figueiredo, J.L. Faria, H.T. Gomes, Catal. Today 280 (2017) 184-191.

[66] R.S. Ribeiro, A.M.T. Silva, J.L. Figueiredo, J.L. Faria, H.T. Gomes, Catal. Today 296 (2017) 66-75. 